\title{
$\Delta 1$-Dehydrogenation and C20 Reduction of Cortisone and Hydrocortisone Catalyzed by Rhodococcus Strains
}

\author{
Stefania Costa ${ }^{1, *}$, Federico Zappaterra ${ }^{1}$, Daniela Summa ${ }^{2}$, Bruno Semeraro ${ }^{2}$ \\ and Giancarlo Fantin ${ }^{3}$ \\ 1 Department of Life Sciences and Biotechnology, University of Ferrara, Via L. Borsari, 46, 44121 Ferrara, Italy; \\ federico.zappaterra@unife.it \\ 2 GATE SRL, Via L. Borsari, 46, 44121 Ferrara, Italy; daniela.summa@unife.it (D.S.); bsemeraro@gategreen.it (B.S.) \\ 3 Department of Chemical and Pharmaceutical Sciences, University of Ferrara, Via L. Borsari, 46, \\ 44121 Ferrara, Italy; giancarlo.fantin@unife.it \\ * Correspondence: stefania.costa@unife.it; Tel.: +39-0532-455-708
}

Received: 26 March 2020; Accepted: 4 May 2020; Published: 7 May 2020

check for updates

\begin{abstract}
Prednisone and prednisolone are steroids widely used as anti-inflammatory drugs. Development of the pharmaceutical industry is currently aimed at introducing biotechnological processes and replacing multiple-stage chemical syntheses. In this work we evaluated the ability of bacteria belonging to the Rhodococcus genus to biotransform substrates, such as cortisone and hydrocortisone, to obtain prednisone and prednisolone, respectively. These products are of great interest from a pharmaceutical point of view as they have higher anti-inflammatory activity than the starting substrates. After an initial lab-scale screening of 13 Rhodococcus strains, to select the highest producers of prednisone and prednisolone, we reported the $200 \mathrm{ml}$-batch scale-up to test the process efficiency and productivity of the most promising Rhodococcus strains. R. ruber, R. globerulus and $R$. coprophilus gave the $\Delta 1$-dehydrogenation products of cortisone and hydrocortisone (prednisone and prednisolone) in variable amounts. In these biotransformations, the formation of products with the reduced carbonyl group in position $C_{20}$ of the lateral chain of the steroid nucleus was also observed (i.e., $20 \beta$-hydroxy-prednisone and $20 \beta$-hydroxy-prednisolone). The yields, the absence of collateral products, and in some cases the absence of starting products allow us to say that cortisone and hydrocortisone are partly degraded.
\end{abstract}

Keywords: cortisone; hydrocortisone; biotransformations; prednisone; prednisolone; 20ß-hydroxy-prednisone; 20ß-hydroxy-prednisolone; Rhodococcus spp.

\section{Introduction}

Steroids are lipids belonging to the terpenes class, and from a chemical-structural point of view they contain a tetracyclic system of carbon atoms (cyclopentanoperhydrophenanthrene). This type of compound is widespread in nature: thousands of steroids have been identified in living systems. Over 250 sterols and related compounds have been reported to occur in plants (e.g., phytosterols, diosgenin, and brassinosteroids), insects (e.g., ecdysteroids), vertebrates (e.g., cholesterol; corticosteroids: glucocorticoids, mineralocorticoids; sex hormones: androgens, estrogens; bile acids, vitamin D; and neurosteroids), and lower eukaryotes: yeasts and fungi (e.g., ergosterol and ergosteroids) [1-3].

Steroid-based drugs present a broad range of therapeutic applications and represent the highest marketed category of pharmaceuticals, after antibiotics, with an annual production of more than one 
million tons. Currently, about 300 steroid drugs are known, and this number tends to grow. Their production represents the second category in the pharmaceutical market after antibiotics [4].

A large number of steroids are used as anti-inflammatory agents, immunosuppressants, progestational agents, diuretics, anabolics, and contraceptives [5-7]. Some steroid compounds are used for the treatment of prostate and breast cancer [8], as replacement therapy in patients with primary or secondary adrenal insufficiency, as adrenal suppression therapy in congenital adrenal hyperplasia and glucocorticoid resistance for adrenal insufficiency [9], for the prevention of heart disease [10], as antifungal agents [11], and as active ingredients useful for the treatment of obesity [12] and AIDS [13]. Recently, the antiviral activity against the herpes simplex virus type I of some steroid glycosides was determined [14].

The structure of steroids is closely related to their biological activity, i.e., the type, number, and regio and stereo position of the functional groups attached to the steroid core and the oxidation state of the rings. For example, the presence of an oxygen-containing functional group at $C_{11 \beta}$ is crucial for inflammatory activity, the hydroxyl group linked to $C_{17 \beta}$ determines the androgenic properties, the aromatization of ring A results in estrogenic effects, and the corticoids have a 3-oxo-5-ene moiety and the pregnane side chain at $C_{17}[5,15]$.

In this field, corticosteroids are a group of hormones, produced by the adrenal gland cortex, belonging to the steroid class. They are used for their anti-inflammatory and immunosuppressive properties and for their effects on metabolism. They are divided into glucocorticoids, which control the metabolism of carbohydrates, lipids, and proteins, and mineralcorticoids, which control the electrolyte levels and the amount of water present in the blood.

Cortisone and cortisol (hydrocortisone) belong to the glucocorticoid class. They are characterized by the presence of a ketone group in position $\mathrm{C}_{3}$, a double bond in position $\mathrm{C}_{4}$, and a chain $\mathrm{COCH}_{2} \mathrm{OH}$ in $\mathrm{C}_{17}$, and they differ from each other by the fact that in the $\mathrm{C}_{11}$ position cortisone has a carbonyl group while in the structure of hydrocortisone there is a hydroxyl group (Figure 1).
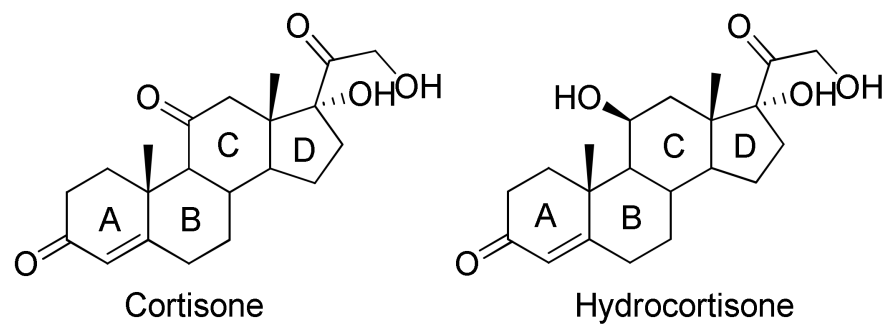

Figure 1. Chemical structures of cortisone and hydrocortisone.

Cortisone and hydrocortisone have a well-known anti-inflammatory activity, and it is equally known that the presence of additional/second double bond at the $C_{1}-C_{2}$ position in prednisone and prednisolone increases the mentioned activity: in particular $\Delta 1$-hydrocortisone (prednisolone) acetate is four times more active than hydrocortisone acetate [16].

Therapeutic effects of steroids can often parallel undesirable side effects, especially when high doses and long-term therapy are required. For this reason the use of more powerful drugs, such as prednisone and prednisolone, can reduce these effects as a lower dose of drug is administered to obtain the same therapeutic effect; prednisone and prednisolone have in fact proved to be four to five times more active than cortisone and hydrocortisone [17].

The synthesis of prednisone and prednisolone by chemical methods requires various reaction steps, in particular regarding prednisone as there are various ways of synthesizing it. In one of these, it is synthesized from dihydrocortisone acetate. In the given example, this compound undergoes dibromination by molecular bromine, giving a 2,4-dibromo derivative of dihydrocortisone. Dehydrobromination with 3,5-lutidine, followed by subsequent hydrolysis of the acetyl group using potassium bicarbonate, gives prednisone [18] (Figure 2). 
<smiles>CC(=O)COC(=O)C[C@@]12CC(=O)C3C(CCC4CC(=O)CC[C@@]43C)C1CC[C@]2(O)C(=O)COC(C)=O</smiles>

dihydrocortisone acetate

2,4-dibromo derivative of dihydrocortisone

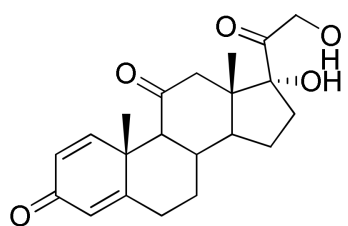

prednisone

Figure 2. Synthesis of prednisone starting from dihydrocortisone acetate.

As for the chemical synthesis of prednisolone, one of various strategies starts from 21 -acetoxy-11 $\beta, 17 \alpha$-dihydroxy- $5 \alpha$-pregnan-3,20-dione, which undergoes dibromination by molecular bromine in acetic acid at positions $\mathrm{C}_{2}$ and $\mathrm{C}_{4}$, and then the resulting dibromide is dehydrobrominated by heating it in collidine, which gives prednisolone as an acetate at position $\mathrm{C}_{21}$. Hydrolyzing this compound leads to the formation of prednisolone [18] (Figure 3).

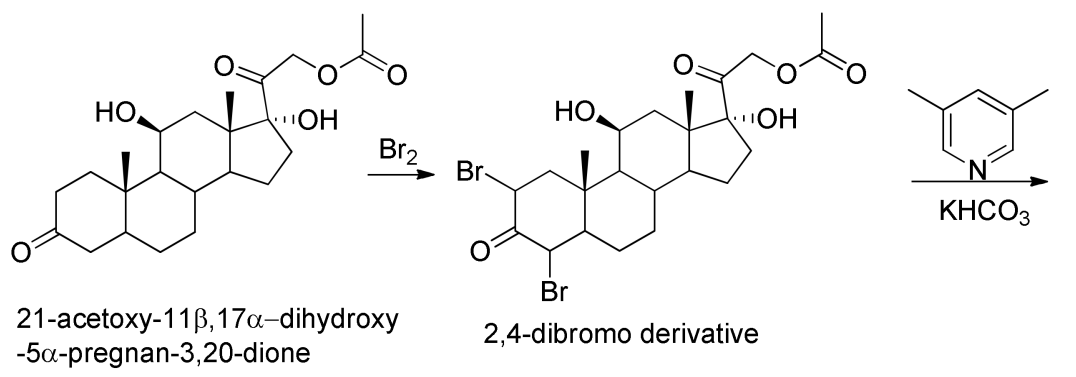

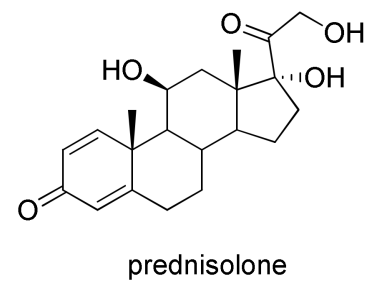

Figure 3. Synthesis of prednisolone starting from 21 -acetoxy-11 $\beta, 17 \alpha$-dihydroxy-5 $\alpha$-pregnan-3,20-dione.

In order to overcome all the problems deriving from chemical synthesis, the potential of microbial steroid biotransformation has been known for several decades, as its application offers a number of advantages over chemical synthesis. These advantages concern (i) the regio- and/or stereospecific functionalization of molecules at positions not always available for chemical agents, (ii) how multiple consecutive reactions are carried out in a single operation step, and (iii) more ecofriendly processes (i.e., mild reaction conditions and aqueousmedia), as several studies have been conducted on the biotransformations of steroid compounds [19].

Recently the biotransformation of cortisone acetate and hydrocortisone acetate with Arthrobacter simplex (Pimelobacter simplex) to the corresponding prednisone acetate [20-22] and prednisolone acetate [23] has been reported. Moreover, prednisolone is also obtained from hydrocortisone by biotransformation with Arthrobacter simplex [24] using recombinant 3-ketosteroid- $\Delta 1$-dehydrogenases [25] and as a hydrocortisone biometabolite from unicellular microalgal cultures [26]. Furthermore, recently the $11 \beta$-reduction of prednisone by biotransformation capacities were confirmed to produce prednisolone [27].

On the other hand, biotransformations are widely used to obtain new steroidal derivatives that can have some therapeutic advantages, such as higher activity, longer half-life, and reduced side effects. In this field, various microorganisms afford the 20 $\beta$-hydroxy-prednisone from prednisone [28] and 20ß-hydroxy-prednisolone from prednisolone [29,30].

The Actinobacteria have been widely studied and their biotransformation capacities confirmed in various types of transformations of steroid rings, such as the reduction of the C-C and C-O double bonds, oxidation of the hydroxyl $(\mathrm{OH})$ group, dehydrogenation and hydroxylation, and in many cases also in the lateral-chain degradation processes or the total degradation of the steroid ring [31].

Rhodococci belong to the order of Actinomycetales, they are gram-positive, obligate aerobic, non-mobile, and non-sporulating bacteria that are usually found in soil and aquatic environments 
and are considered very important as they can be used industrially [32]. Several studies have shown that the species belonging to this genus are able to grow both in mesophilic conditions [33] and in psychrophilic conditions [34].

In particular, Rhodococcus include aerobic bacterial species important for their ability to biotransform a wide range of steroids via hydroxylation or Bayer-Villiger oxidation, while the Corynebacterium and Nocardia genera are known to provide dehydrogenation products [31].

Moreover, in previous works the biotransformations of various bile acids with Rhodococcus spp. have been reported and $\Delta 1$-dehydrogenation, the partial degradation of the $\mathrm{C}_{17}$-side chain together with new 9,10-secosteroids derivatives, has been achieved [35,36]. The highlighted ability of these microorganisms to hydroxylate and dehydrogenate the steroid ring system prompted us to test the capabilities of various Rhodococcus strains towards the biotransformation of cortisone and hydrocortisone.

The purpose of this work is to evaluate the biotransformative capacity of some bacteria belonging to the Rhodococcus genus using cortisone and hydrocortisone as substrates with the aim of isolating products with greater therapeutic activity than the starting compounds. In this study we present the results of a preliminary screening followed by the isolation and characterization of the products obtained from batch cultures of the microorganisms that tested positive for the screening (strains with capacity to transform the cortisone and/or hydrocortisone).

After an initial lab-scale screening where 13 representatives of the Rhodococcus genus were tested towards the biotransformation of cortisone and hydrocortisone, preparative cultures of the strains that were found to be positive to verify the biotransformation of the products and their yields were set up.

\section{Results and Discussion}

\subsection{Rhodococcus Screening and Selection}

Due to the numerous harmful and dangerous effects of the reagents used in the chemical synthesis of prednisone and prednisolone, research is increasingly turning towards greener approaches. The use of bromine in the chemical synthesis can cause an explosive risk as well as irritating and respiratory effects if you come into contact with this reagent, also as regards 3,5-lutidine there are particular risks as it is flammable corrosive and toxic. To overcome all these problems, the biotransformative approach using non-pathogenic microorganisms has proved to be of great interest for the mild reaction conditions and the water-based culture medium of the microorganisms. In previous studies it has been shown that there is much evidence of the capacity of Rhodococcus strains to biotransform steroidal substrates to have $\Delta 1$-dehydrogenation products. [35,36]. Starting from these results, 13 Rhodococcus strains in the biotransformations of cortisone and hydrocortisone were tested. Screening tests were carried out in order to select microrganisms able to biotransformate these substrates. In Table 1 results of this screening are reported with the relative retention factors (Rf) of the product obtained.

Some of the tested bacteria were able to biotransform the administered substrates in particular, regarding the biotransformations of cortisone, R. globerulus, R. aetherivorans, R. coprophilus, R. ruber, and $R$. rhodochrous DSM 43273 converted the starting substrate into a product having Rf equal to 0.55 . The reactions conducted with $R$. erythropholis and $R$. baikonurensis, in addition to the product just mentioned, generated another compound with an Rf of 0.23 .

Biotransformation activity has not been verified with R. opacus, R. fascians, Rhodococcus sp. R312, R. rhodochrous NCIMB 11216, and R. equi.

In the biotransformation of cortisone R. zopfii exhibited a particular behavior leading to a complete degradation of the substrate without providing biotransformation products. In this regard, it is known that some microorganisms are able to use steroids as a carbon source, degrading the lateral chain and subsequently the steroid nucleus, reaching complete mineralization [36].

Figure 4 shows the probable degradation pathway of cortisone by Actinobacteria [31] based on the literature data. 
Table 1. Analitical results of Rhodococcus screening in biotransformation of cortisone and hydrocortisone.

\begin{tabular}{ccc}
\hline Bacteria & Products from Cortisone & Products from Hydrocortisone \\
\hline R. zopfii & Degradation & Rf 0.45 \\
R. opacus & no product & no product \\
R. fascians & no product & no product \\
R. baikonurensis & Rf $0.23,0.55$ & Rf 0.21 \\
R. globerulus & Rf 0.55 & Rf 0.45 \\
R. aetherivorans & Rf 0.55 & no product \\
R. coprophilus & Rf 0.55 & Rf 0.45 \\
R. rhodochrous NCIMB 11216 & no product & no product \\
Rhodococcus sp. R312 & no product & no product \\
R. equi & no product & no product \\
R. ruber & Rf 0.55 & Rf 0.45 \\
R. rhodochrous DSM 43273 & Rf 0.55 & degradation \\
R. erythropholis & Rf $0.23,0.55$ & Rf $0.45,0.21$ \\
\hline
\end{tabular}

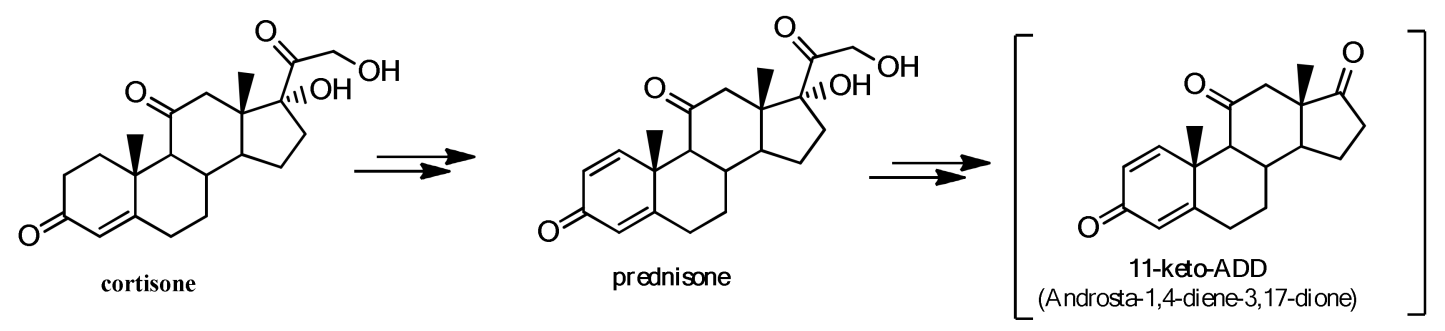

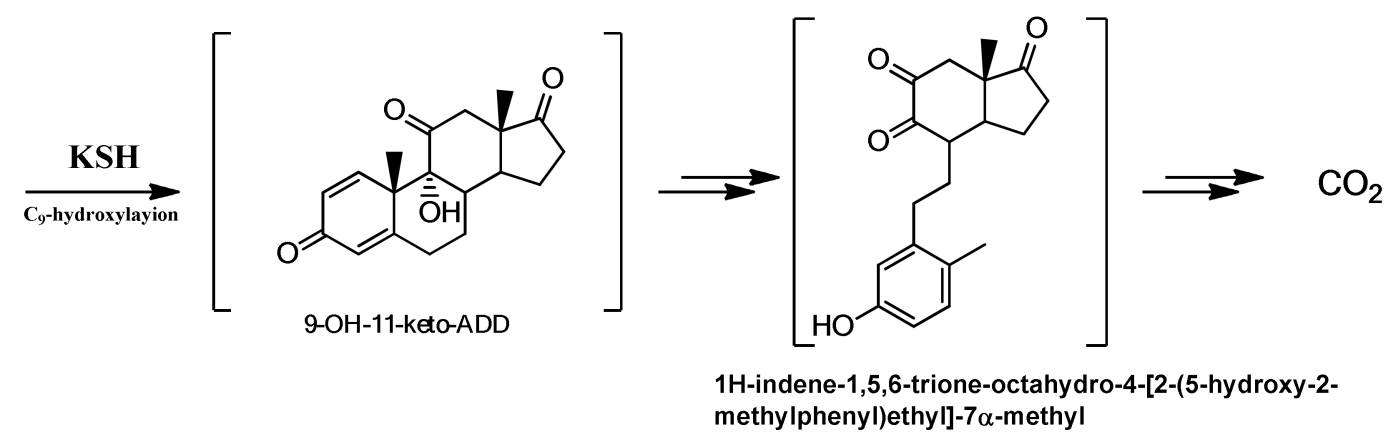

Figure 4. Metabolic pathway of steroid degradation.

Steroids with 3-oxo-4-ene structure, such as cortisone and hydrocortisone, are subjected to the cleavage of ring $\mathrm{B}$. The $\Delta 1$-dehydrogenation of cortisone to give prednisone is the initial stage that leads to the complete elimination of the $\mathrm{C}_{17}$ chain with the ADD (androstadienedione) formation. This is a classic step in the degradation of other steroids, such as sitosterols, testosterone, and bile acids [37].

ADD is subjected to hydroxylation at the $C_{9}$-position catalyzed by 3-ketosteroid- $9 \alpha$-hydroxylase (KSH), a two-component iron-sulfur-containing monooxygenase [38-40]. This reaction leads to the spontaneous cleavage of the ring $\mathrm{B}$ by a retro-aldol cleavage and the formation of the aromatic 9,10-secosteroids, which undergo further degradation [41].

Because of this knowledge we can, therefore, assume that the $\Delta 1$-dehydrogenation is the initial stage that leads to the degradation of the $\mathrm{C}_{17}$-chain and to the opening of the ring $\mathrm{B}$ and subsequently to the total degradation of cortisone. Furthermore non-quantitative yields and the absence of collateral products and starting product confirm this assumption.

As for the biotransformations of hydrocortisone, in most cases a single product with an Rf of 0.45 was obtained, only in one case with $R$. baikonurensis a compound with an Rf of 0.21 was detected, while $R$. erythropholis was the only microorganism able to produce two compounds ( $\operatorname{Rf} 0.45$ and 0.21 ). $R$. rhodochrous DSM 43273 had completely metabolized the starting substrate without providing 
detectable products through thin-layer chromatography (TLC) analysis. Most likely, R. rhodochrous DSM 43273 completely degraded the carbon source following a metabolic pathway similar to that of cortisone as previously described. Finally, R. opacus, R. fascians, R. aetherivorans, R. rhodochrous NCIMB 11216, Rhodococcus sp. R312, and R. equi showed no biotransformative capacity towards hydrocortisone.

\subsection{Characterization of the Biotransformation Products of Cortisone}

Semi-preparative cultures were necessary to isolate and identify the biotransformation products. The identification of the products was carried out by NMR analysis, comparing the signals obtained with those of the spectra present in the literature. In general, from the biotransformation of cortisone with Rhodococcus species, two products were obtained: prednisone and $20 \beta$-hydroxy-prednisone, the first being the product of the dehydrogenation of the $C_{1}-C_{2}$ bond in cortisone, while $20 \beta$-hydroxy-prednisone in addition to $\Delta^{1}$-dehydrogenation presents the reduction of the carbonyl group in the position $C_{20 \beta}$ as shown in Figure 5.

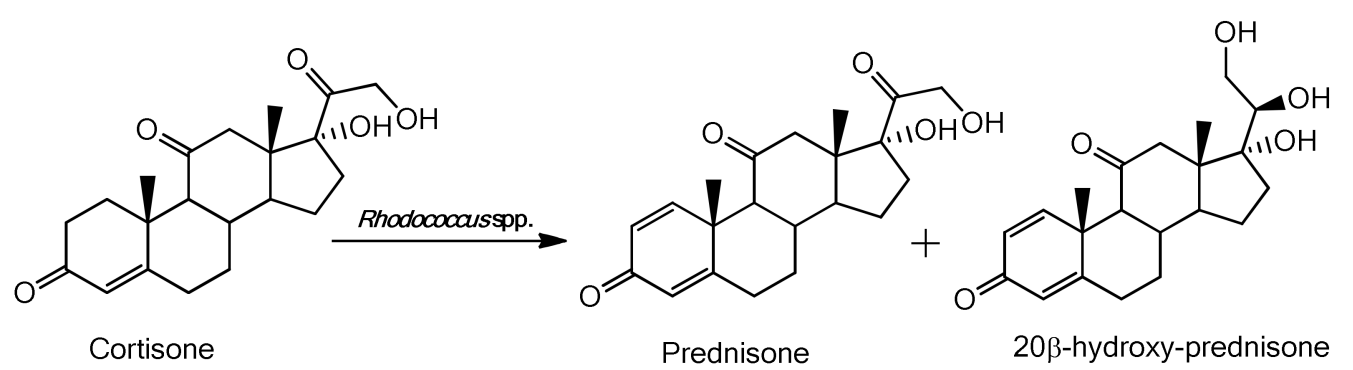

Figure 5. Products obtained from biotransformation of cortisone with Rhodococcus spp.

Table 2 shows the products of the biotransformations of cortisone with the relative yields and reaction times; the quantity of residual cortisone is also specified. The biotransformation yields were obtained by working out the percentage of the ratio between the moles of the product obtained compared to the moles of the administered substrate. The relative standard deviation value for statistical analysis was also reported.

The product of $\Delta^{1}$-dehydrogenation (prednisone) was the only one obtained from the biotransformations with $R$. globerulus, $R$. aetherivorans, R. coprophilus, $R$. ruber, and $R$. rhodochrous DSM 43273. Among these bacteria, only in one case (R. coprophilus after $24 \mathrm{~h}$ of biotransformation), was no residual cortisone observed, and the yield was very high (94\%). This result clearly underlines this strategy as a valid alternative to the chemical synthesis of prednisone, since the time of biotransformation is rather short when whole cells are rather short, and the yield of the product is almost quantitative. Regarding the biotransformations of cortisone with R. globerulus, R. aetherivorans, and R. ruber after $72 \mathrm{~h}$ of incubation with the substrate, yields of prednisone production were quite similar: $33 \%$ with R. globerulus, and $35 \%$ and $52 \%$ with $R$. aetherivorans and R. ruber, respectively. In these cases, variable amounts of cortisone residue were observed (47-65\%). The ${ }^{1} \mathrm{H}-$ and ${ }^{13} \mathrm{C}-\mathrm{NMR}$ spectra showed the characteristic signals of the $\mathrm{C}_{1}-\mathrm{C}_{2}$ double bond at $6.19\left(\mathrm{C}_{2}-\mathrm{H}\right), 7.63\left(\mathrm{C}_{1}-\mathrm{H}\right), 127.7\left(\mathrm{C}_{2}\right)$, and $158.4\left(\mathrm{C}_{1}\right)$ ppm of prednisone. On the other hand, in biotransformations carried out with $R$. baikonurensis and R. erythropolis, after $72 \mathrm{~h}$ of reaction, in addition to prednisone with yields of $27 \%$ and $33 \%$ respectively, both bacteria produced a new compound corresponding to $20 \beta$-hydroxy-prednisone (yield $68 \%$ for R. baikonurensis and $37 \%$ for R. erythropolis). The stereochemistry of the $\mathrm{C}_{20}$-reduction is confirmed by comparing the ${ }^{1} \mathrm{H}-\mathrm{NMR}$ data (i.e., $4.61\left(\mathrm{C}_{20}-\mathrm{H}\right)$ and $4.52\left(\mathrm{C}_{21}-\mathrm{H}\right) \mathrm{ppm}$ in $\left.\mathrm{C}_{5} \mathrm{D}_{5} \mathrm{~N}\right)$ and ${ }^{13} \mathrm{C}-\mathrm{NMR}$ data (i.e., $65.0\left(\mathrm{C}_{21}\right)$ and $72.5\left(\mathrm{C}_{20}\right) \mathrm{ppm}$ ) with data recorded for the commercially available compound. This product could be an interesting derivative of the bioactive prednisone. 
Table 2. Biotransformations of cortisone with Rhodococcus spp.

\begin{tabular}{|c|c|c|c|c|}
\hline Bacteria & $\begin{array}{c}\text { Time of } \\
\text { Biotransformation } \\
\text { (h) }\end{array}$ & $\begin{array}{l}\text { Prednisone } \\
\text { (\% Yield) }\end{array}$ & $\begin{array}{l}\text { 20ß-Hydroxy-Prednisone } \\
\text { (\% Yield) }\end{array}$ & $\begin{array}{c}\text { Cortisone Residue } \\
(\%)\end{array}$ \\
\hline R. baikonurensis & 72 & $\begin{array}{c}27 \pm 3 \\
(0.053 \pm 0.005 \mathrm{~g})\end{array}$ & $\begin{array}{c}68 \pm 4 \\
(0.134 \pm 0.007 \mathrm{~g})\end{array}$ & - \\
\hline R. globerulus & 72 & $\begin{array}{c}33 \pm 6 \\
(0.065 \pm 0.012 \mathrm{~g})\end{array}$ & - & $\begin{array}{c}65 \pm 3 \\
(0.129 \pm 0.006 \mathrm{~g})\end{array}$ \\
\hline R. aetherivorans & 72 & $\begin{array}{c}35 \pm 3 \\
(0.069 \pm 0.006 \mathrm{~g})\end{array}$ & - & $\begin{array}{c}63 \pm 7 \\
(0.125 \pm 0.014 \mathrm{~g})\end{array}$ \\
\hline R. coprophilus & 24 & $\begin{array}{c}94 \pm 2 \\
(0.185 \pm 0.004 \mathrm{~g})\end{array}$ & - & (10 \\
\hline R. ruber & 72 & $\begin{array}{c}52 \pm 4 \\
(0.102 \pm 0.008 \mathrm{~g})\end{array}$ & - & $\begin{array}{c}47 \pm 4 \\
(0.093 \pm 0.008 \mathrm{~g})\end{array}$ \\
\hline $\begin{array}{l}\text { R. rhodochrous DSM } \\
43273\end{array}$ & 72 & $\begin{aligned} 31 & \pm 3 \\
(0.0065 & \pm 0.006)\end{aligned}$ & & $\begin{array}{c}53 \pm 3 \\
(0.105 \pm 0.006)\end{array}$ \\
\hline R. erythropolis & 72 & $\begin{array}{c}33 \pm 5 \\
(0.065 \pm 0.01 \mathrm{~g})\end{array}$ & $\begin{array}{c}37 \pm 6 \\
(0.073 \pm 0.011 \mathrm{~g})\end{array}$ & $\begin{array}{c}28 \pm 6 \\
(0.056 \pm 0.012 \mathrm{~g})\end{array}$ \\
\hline
\end{tabular}

\subsection{Characterization of the Biotransformation Products of Hydrocortisone}

As in the biotransformation of cortisone, in the case of hydrocortisone two types of compound were also obtained: prednisolone, deriving from the $\Delta^{1}$-dehydrogenation of the ring $\mathrm{A}$, and $20 \beta$-hydroxy-prednisolone, which is a product of the reduction of the carbonyl group in the side chain $\left(\mathrm{C}_{20}\right)$ as shown in Figure 6.

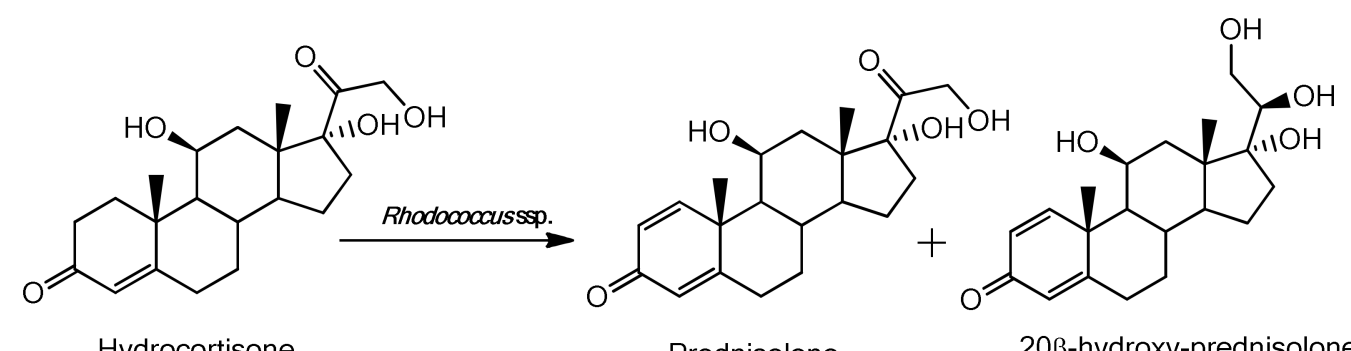

Figure 6. Products obtained from biotransformation of hydrocortisone with Rhodococcus spp.

The products obtained from the biotransformations of hydrocortisone with their relative yields and reaction times are reported in Table 3, and the quantities of residual hydrocortisone are also reported (where present). Yield percentages of biotrasformation have been calculated on the basis of the weights of the products obtained after chromatography separation. The relative standard deviation value for statistical analysis was also reported.

Table 3. Biotransformations of hydrocortisone with Rhodococcus spp.

\begin{tabular}{|c|c|c|c|c|}
\hline Bacteria & $\begin{array}{c}\text { Time of } \\
\text { Biotransformation } \\
\text { (h) }\end{array}$ & $\begin{array}{l}\text { Prednisolone } \\
\text { (\% Yield) }\end{array}$ & $\begin{array}{l}\text { 20ß-Hydroxy-Prednisolone } \\
\text { (\% Yield) }\end{array}$ & $\begin{array}{l}\text { Hydrocortisone } \\
\text { Residue } \\
(\%)\end{array}$ \\
\hline R. baikonurensis & 72 & - & $\begin{array}{c}32 \pm 3 \\
(0.063 \pm 0.006 \mathrm{~g})\end{array}$ & - \\
\hline R. globerulus & 72 & $\begin{array}{c}76 \pm 2 \\
(0.151 \pm 0.004 \mathrm{~g})\end{array}$ & (5) & $\begin{array}{c}23 \pm 1 \\
(0.045 \pm 0.002 \mathrm{~g})\end{array}$ \\
\hline R. coprophilus & 24 & $\begin{array}{c}97 \pm 2 \\
(0.192 \pm 0.004 \mathrm{~g})\end{array}$ & - & 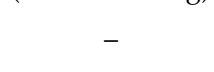 \\
\hline R. ruber & 72 & $\begin{array}{c}56 \pm 4 \\
(0.111 \pm 0.009 \mathrm{~g})\end{array}$ & - & $\begin{array}{c}40 \pm 4 \\
(0.072 \pm 0.007 \mathrm{~g})\end{array}$ \\
\hline R. erythropolis & 72 & $\begin{array}{c}37 \pm 5 \\
(0.073 \pm 0.01 \mathrm{~g})\end{array}$ & $\begin{array}{c}40 \pm 8 \\
(0.079 \pm 0.016 \mathrm{~g})\end{array}$ & $\begin{array}{c}18 \pm 6 \\
(0.035 \pm 0.012 \mathrm{~g})\end{array}$ \\
\hline
\end{tabular}


$R$. coprophilus is the only microrganism able to bioconvert hydrocortisone after $24 \mathrm{~h}$ in prednisolone with a yield equal to $97 \%$ without the presence of residual hydrocortisone; the ${ }^{1} \mathrm{H}$ and ${ }^{13} \mathrm{C}$-NMR spectra show the characteristic signals $6.27\left(\mathrm{C}_{2}-\mathrm{H}\right), 7.24\left(\mathrm{C}_{1}-\mathrm{H}\right), 127.1\left(\mathrm{C}_{2}\right)$ and $156.8\left(\mathrm{C}_{1}\right)$ ppm of prednisolone. R. globerulus and R. ruber afforded the same product after $72 \mathrm{~h}$ of reaction with different yields $(76 \%$ and $56 \%$, respectively), but in these cases a certain amount of residual hydrocortisone was observed.

R. baikonurensis transformed hydrocortisone into $20 \beta$-hydroxy-prednisolone without recovering hydrocortisone. The stereochemistry of the $\mathrm{C}_{20}$-reduction is supported by the comparison of the recorded NMR data with the data given in the literature [29]: $3.85\left(\mathrm{C}_{20}-\mathrm{H}\right), 3.91\left(\mathrm{C}_{21}-\mathrm{H}\right), 65.3\left(\mathrm{C}_{21}\right)$, and $79.1\left(\mathrm{C}_{20}\right) \mathrm{ppm}$. The yield after $72 \mathrm{~h}$ of biotransformation is quite low $(32 \%)$, and a possible explanation may be that the enzymes of the microorganism are able to form 20 $\beta$-hydroxy-prednisolone and subsequently the substrate is metabolized via the steroid degradation pathway described previously. This process includes the initial oxidation of the ring A, degradation of the side chain, and finally complete mineralization.

Finally, R. erythropolis provided both the prednisolone and the 20ß-hydroxy-prednisolone biotransformation products with yields of $37 \%$ and $40 \%$, respectively, after a 72 -hour-reaction. In this case, even using the maximum biotransformation time, $18 \%$ of residual hydrocortisone was recovered.

\section{Materials and Methods}

\subsection{Chemicals and Rhodococcus Strains}

Cortisone and hydrocortisone were purchased from Merck KGaA (Darmstadt, Germany), and 20 $\beta$-hydroxy-prednisone was purchased from Toronto Research Chemical Inc. (Toronto, Canada). Plate count broth (PCB) is commercially available from Oxoid (Basingstoke, UK) and contains tryptone enzymatic digest from casein $5 \mathrm{~g} / \mathrm{L}$, yeast extract $2.5 \mathrm{~g} / \mathrm{L}$, and glucose $1 \mathrm{~g} / \mathrm{L}$. All the other chemicals were purchased from Fluka Analytical (Steinheim, Germany) unless otherwise stated.

The 13 Rhodococcus strains belong to the collection of microorganisms of the Life Sciences and Biotechnology Department of the University of Ferrara and they were purchased from the DSMZ (Leibniz Institute DSMZ-German Collection of Microorganisms and Cell Cultures GmbH) company (Table 4). The master cell bank of every strain was maintained at $-20{ }^{\circ} \mathrm{C}$ in cryovials in Plate count broth medium $(1 \mathrm{~mL})$ mixed with glycerol $(0.5 \mathrm{~mL})$ as a crioprotectant agent. The working cell bank was conserved at $4{ }^{\circ} \mathrm{C}$ in plate count agar (PCA) slants for 6 months and used for seed cultures.

Table 4. Rhodococcus strains used for biotransformation screening of cortisone and hydrocortisone.

\begin{tabular}{llcc}
\hline$\#$ & Genus & Species & Identification Code \\
\hline 1 & Rhodococcus & zopfii & DSM 44108 \\
2 & Rhodococcus & opacus & DSM 43250 \\
3 & Rhodococcus & fascians & DSM 43985 \\
4 & Rhodococcus & baikonurensis & DSM 44587 \\
5 & Rhodococcus & globerulus & DSM 43954 \\
6 & Rhodococcus & aetherivorans & DSM 44752 \\
7 & Rhodococcus & coprophilus & DSM 43347 \\
8 & Rhodococcus & rhodochrous & NCIMB 11216 \\
9 & Rhodococcus & sp. R312 & CBS 717.73 \\
10 & Rhodococcus & equi & IFO 3730 \\
11 & Rhodococcus & ruber & DSM 6264 \\
12 & Rhodococcus & rhodochrous & DSM 43273 \\
13 & Rhodococcus & erythropholis & DSM 43188 \\
\hline
\end{tabular}

\subsection{Rhodococcus Biotransformation Screening Conditions}

For each of the selected Rhodococcus strains, a loopful of bacterial cells cultured on the plate count agar was transferred to $50 \mathrm{~mL}$ Erlenmeyer flasks containing $10 \mathrm{~mL}$ of sterile PCB medium and 
incubated at $30{ }^{\circ} \mathrm{C}$ and $110 \mathrm{rpm}$ in an orbital shaker for $48 \mathrm{~h}$. Each microorganism was inoculated in three Erlenmeyer flasks, closed with cotton plugs, and submitted to the same protocol.

After the bacteria were grown, a solution of the substrate (cortisone or hydrocortisone) in dimethylsulfoxide (DMSO) (0.1 mL containing $10 \mathrm{mg}$ of substrate) was added. The course of the reactions was followed by withdrawing samples $(1 \mathrm{~mL})$ every $24 \mathrm{~h}$ up to $72 \mathrm{~h}$ from the administration of the substrate. The reactions were stopped after $72 \mathrm{~h}$, as no significant differences were observed between the results of the TLC analysis performed at $48 \mathrm{~h}$ and $72 \mathrm{~h}$. Samples were then centrifuged ( $6720 \mathrm{RCF} ; 10 \mathrm{~min}$ ) in order to remove the cells, and the supernatants were extracted with ethyl acetate and immediately analyzed by TLC on silica gel using ethyl acetate as an eluent.

\subsection{Semi-Preparative Biotransformation Protocol}

The biotransformations showing additional spots other than the starting material were repeated on a semipreparative scale $(200 \mathrm{~mL})$ in order to isolate the products. For each of the selected Rhodococcus strains, a loopful of bacterial cells cultured on PCA was transferred to $50 \mathrm{~mL}$ Erlenmeyer flasks containing $20 \mathrm{~mL}$ of sterile PCB medium and incubated at $30^{\circ} \mathrm{C}$ and $110 \mathrm{rpm}$ in an orbital shaker for $48 \mathrm{~h}$. The whole culture was introduced into a $500 \mathrm{~mL}$ Erlenmeyer flask containing $200 \mathrm{~mL}$ of sterile PCB, and after $48 \mathrm{~h}$ incubation at $30^{\circ} \mathrm{C}$ and $110 \mathrm{rpm}$, the substrate $(0.2 \mathrm{~g})$ in DMSO $(2 \mathrm{~mL})$ was added and the culture was maintained in the same conditions for a maximum of $72 \mathrm{~h}$. All tests were carried out in triplicate for statistical significance. A blank sample was also incubated containing all the reagents but no bacteria. The reaction course was monitored by withdrawing samples $(1 \mathrm{~mL})$ every $24 \mathrm{~h}$ up to $72 \mathrm{~h}$ of reaction, and the semipreparative reactions were followed by TLC analysis and stopped when the higher conversion was reached. TLC analysis was performed using $1 \mathrm{~mL}$ of sample taken every $24 \mathrm{~h}$ from the flask in which the reaction was conducted. The sample was subsequently subjected to centrifugation, extraction with ethyl acetate, and immediately analyzed using TLC on silica gel using ethyl acetate as an eluent, following the same protocol used in the screening procedure.

The cells were removed by centrifugation ( $5242 \mathrm{RCF}, 20 \mathrm{~min}$ ) and the supernatant was extracted with ethyl acetate $(3 \times 80 \mathrm{~mL})$. The organic layer was dried over anhydrous $\mathrm{Na}_{2} \mathrm{SO}_{4}$, the solvent was evaporated, and the crude mixture was purified on a chromatographic column (silica gel, ethyl acetate/cyclohexane 50/50 as an eluent). The biotransformation yields were obtained by working out the percentage of the ratio between the moles of the product obtained compared to the moles of the administered substrate.

\subsection{Analitical Methods}

TLC was performed on precoated silica gel plates (thickness $0.25 \mathrm{~mm}$, Merck) and silica gel (Fluka, Kiesegel 60, 70-230 mesh) was used for preparative column chromatography.

Melting points are uncorrected and were determined on a 510 Büchi melting point instrument.

${ }^{1} \mathrm{H}$ and ${ }^{13} \mathrm{C}$ NMR spectra were obtained with a Varian Gemini 300 spectrometer operating at $300 \mathrm{MHz}$ $\left({ }^{1} \mathrm{H}\right)$ and $100 \mathrm{MHz}\left({ }^{13} \mathrm{C}\right)$, with $\mathrm{Me}_{4} \mathrm{Si}$ as an internal standard.

\subsection{Compound Data}

$17 \alpha, 21$-dihydroxy-1,4-pregnadiene-3,11,20-trione (prednisone): m.p. $234{ }^{\circ} \mathrm{C} ;{ }^{1} \mathrm{H}-\mathrm{NMR}\left(\mathrm{CDCl}_{3}\right): \delta$ $0.67\left(\mathrm{~s}, 3 \mathrm{H}, \mathrm{C}_{18}-\mathrm{CH}_{3}\right) ; 1.42\left(\mathrm{~s}, 3 \mathrm{H}, \mathrm{C}_{19}-\mathrm{CH}_{3}\right) ; 1.69\left(\mathrm{~m}, 1 \mathrm{H}, \mathrm{C}_{7}-\mathrm{H}\right) ; 1.73\left(\mathrm{~m}, 1 \mathrm{H}, \mathrm{C}_{7}-\mathrm{H}\right) ; 1.92\left(\mathrm{~m} \mathrm{1H} ; \mathrm{C}_{16}-\mathrm{H}\right) ;$ $1.94\left(\mathrm{~m}, 2 \mathrm{H}, \mathrm{C}_{15}-\mathrm{H}\right) ; 1.98\left(\mathrm{~m}, 1 \mathrm{H}, \mathrm{C}_{8}-\mathrm{H}\right) ; 1.98\left(\mathrm{~m}, 1 \mathrm{H}, \mathrm{C}_{6}-\mathrm{H}\right) ; 2.01\left(\mathrm{~m}, 1 \mathrm{H}, \mathrm{C}_{6}-\mathrm{H}\right) ; 1.99(\mathrm{~d}, 1 \mathrm{H}, J=3.1$, $\left.\mathrm{C}_{9}-\mathrm{H}\right) ; 2.06\left(\mathrm{~m}, 1 \mathrm{H}, \mathrm{C}_{14}-\mathrm{H}\right) ; 2.38\left(\mathrm{~m}, 1 \mathrm{H}, \mathrm{C}_{12}-\mathrm{H}\right) ; 2.72\left(\mathrm{~m} \mathrm{1H} ; \mathrm{C}_{16}-\mathrm{H}\right) ; 2.77\left(\mathrm{~m}, 1 \mathrm{H}, \mathrm{C}_{12}-\mathrm{H}\right) ; 4.24(\mathrm{~d}, 1 \mathrm{H}$, $\left.J=20 \mathrm{~Hz}, \mathrm{C}_{21}-\mathrm{H}\right) ; 4.62\left(\mathrm{~d}, 1 \mathrm{H}, J=20 \mathrm{~Hz}, \mathrm{C}_{21}-\mathrm{H}\right) ; 6.07\left(\mathrm{t}, 1 \mathrm{H}, J=1.8 \mathrm{~Hz}, \mathrm{C}_{4}-\mathrm{H}\right) ; 6.19(\mathrm{dd}, 1 \mathrm{H}, J=10.2$ and $\left.1.8 \mathrm{~Hz}, \mathrm{C}_{2}-\mathrm{H}\right) ; 7.63\left(\mathrm{~d}, 1 \mathrm{H}, J=10.2 \mathrm{~Hz}, \mathrm{C}_{1}-\mathrm{H}\right) ;{ }^{13} \mathrm{C}-\mathrm{NMR}(\mathrm{CDCl} 3): \delta 16.2\left(\mathrm{C}_{18}\right) ; 19.3\left(\mathrm{C}_{19}\right) ; 24.1\left(\mathrm{C}_{15}\right)$; $33.3\left(C_{7}\right) ; 34.9\left(C_{6}\right) ; 35.2\left(C_{16}\right) ; 37.4\left(C_{8}\right) ; 44.1\left(C_{10}\right) ; 50.8\left(C_{14}\right) ; 51.1\left(C_{12}\right) ; 52.3\left(C_{13}\right) ; 61.1\left(C_{9}\right) ; 67.8\left(C_{21}\right)$; $89.1\left(C_{17}\right) ; 124.7\left(C_{4}\right) ; 127.8\left(C_{2}\right) ; 158.2\left(C_{1}\right) ; 170.9\left(C_{5}\right) ; 188.6\left(C_{3}\right) ; 211.4\left(C_{11}\right) ; 212.7\left(C_{20}\right)$.

$11 \alpha, 17 \beta, 21$-trihydroxy-1,4-pregnadiene-3,20-dione (prednisolone): m.p. $235^{\circ} \mathrm{C} ;{ }^{1} \mathrm{H}-\mathrm{NMR}\left(\mathrm{CDCl}_{3}\right)$ : $\delta 0.97\left(\mathrm{~s}, 3 \mathrm{H}, \mathrm{C}_{18}-\mathrm{CH}_{3}\right) ; 1.08\left(\mathrm{~d}, 1 \mathrm{H}, \mathrm{C}_{9}-\mathrm{H}\right) ; 1.10\left(\mathrm{~m}, 1 \mathrm{H}, \mathrm{C}_{7}-\mathrm{H}\right) ; 1.45\left(\mathrm{~s}, 3 \mathrm{H}, \mathrm{C}_{19}-\mathrm{CH}_{3}\right) ; 1.45(\mathrm{~m}, 1 \mathrm{H}$, 
$\left.\mathrm{C}_{15}-\mathrm{H}\right) ; 1.55\left(\mathrm{~m}, 1 \mathrm{H}, \mathrm{C}_{16}-\mathrm{H}\right) ; 1.56\left(\mathrm{~m}, 1 \mathrm{H}, \mathrm{C}_{12}-\mathrm{H}\right) ; 1.71\left(\mathrm{~m}, 1 \mathrm{H}, \mathrm{C}_{14}-\mathrm{H}\right) ; 1.72\left(\mathrm{~m}, 1 \mathrm{H}, \mathrm{C}_{15}-\mathrm{H}\right) ; 2.09$ (m, $\left.1 \mathrm{H}, \mathrm{C}_{12}-\mathrm{H}\right) ; 2.13\left(\mathrm{~m}, 1 \mathrm{H}, \mathrm{C}_{7}-\mathrm{H}\right) ; 2.15\left(\mathrm{~m}, 1 \mathrm{H}, \mathrm{C}_{8}-\mathrm{H}\right) ; 2.35\left(\mathrm{~m}, 1 \mathrm{H}, \mathrm{C}_{6}-\mathrm{H}\right) ; 2.57\left(\mathrm{~m}, 1 \mathrm{H}, \mathrm{C}_{6}-\mathrm{H}\right) ; 2.71(\mathrm{~m}$, $\left.1 \mathrm{H}, \mathrm{C}_{16}-\mathrm{H}\right) ; 4.28\left(\mathrm{~d}, 2 \mathrm{H}, \mathrm{C}_{21}-\mathrm{H}\right) ; 4.50\left(\mathrm{~s}, 1 \mathrm{H}, \mathrm{C}_{11}-\mathrm{H}\right) ; 6.02\left(\mathrm{~s}, 1 \mathrm{H}, \mathrm{C}_{4}-\mathrm{H}\right) ; 6.27\left(\mathrm{~d}, 1 \mathrm{H}, \mathrm{C}_{2}-\mathrm{H}\right) ; 7.24(\mathrm{~d}, 1 \mathrm{H}$, $\left.\mathrm{C}_{1}-\mathrm{H}\right) ;{ }^{13} \mathrm{C}-\mathrm{NMR}\left(\mathrm{CDCl}_{3}\right): \delta 16.9\left(\mathrm{C}_{18}\right) ; 20.9\left(\mathrm{C}_{19}\right) ; 23.8\left(\mathrm{C}_{15}\right) ; 31.2\left(\mathrm{C}_{7}\right) ; 31.8\left(\mathrm{C}_{6}\right) ; 33.5\left(\mathrm{C}_{16}\right) ; 34\left(\mathrm{C}_{8}\right) ; 38.9$ $\left(\mathrm{C}_{10}\right) ; 44.1\left(\mathrm{C}_{14}\right) ; 47.1\left(\mathrm{C}_{12}\right) ; 51.1\left(\mathrm{C}_{13}\right) ; 55.4\left(\mathrm{C}_{9}\right) ; 66.5\left(\mathrm{C}_{21}\right)$; $68.9\left(\mathrm{C}_{11}\right) ; 88.6\left(\mathrm{C}_{17}\right) ; 121.8\left(\mathrm{C}_{4}\right) ; 127.1\left(\mathrm{C}_{2}\right)$; $156.8\left(\mathrm{C}_{1}\right) ; 170.5\left(\mathrm{C}_{5}\right) ; 185.8\left(\mathrm{C}_{3}\right) ; 212.1\left(\mathrm{C}_{20}\right)$.

$17 \alpha, 20 \beta, 21$-trihydroxy-1,4-pregnadiene-3,11-dione (20ß-hydroxy-prednisone): m.p.240-242 ${ }^{\circ} \mathrm{C}$; ${ }^{1} \mathrm{H}-\mathrm{NMR}\left(\mathrm{CDCl}_{3}\right): \delta 0.81\left(\mathrm{~s}, 3 \mathrm{H}, \mathrm{C}_{18}-\mathrm{CH}_{3}\right) ; 1.03\left(\mathrm{~m}, 1 \mathrm{H}, \mathrm{C}_{15}-\mathrm{H}\right) ; 1.43\left(\mathrm{~s}, 3 \mathrm{H}, \mathrm{C}_{19}-\mathrm{CH}_{3}\right) ; 1.50(\mathrm{~m}, 1 \mathrm{H}$, $\left.\mathrm{C}_{7}-\mathrm{H}\right) ; 1.77\left(\mathrm{~m}, 1 \mathrm{H}, \mathrm{C}_{6}-\mathrm{H}\right) ; 1.81\left(\mathrm{~m}, 1 \mathrm{H}, \mathrm{C}_{7}-\mathrm{H}\right) ; 1.82\left(\mathrm{~m}, 1 \mathrm{H}, \mathrm{C}_{15}-\mathrm{H}\right) ; 1.90\left(\mathrm{~m}, 1 \mathrm{H}, \mathrm{C}_{14}-\mathrm{H}\right) ; 1.92(\mathrm{~m}, 1 \mathrm{H}$, $\left.\mathrm{C}_{6}-\mathrm{H}\right) ; 1.93\left(\mathrm{~m}, 1 \mathrm{H}, \mathrm{C}_{8}-\mathrm{H}\right) ; 2.01\left(\mathrm{~m}, 1 \mathrm{H}, \mathrm{C}_{16}-\mathrm{H}\right) ; 2.45\left(\mathrm{~m}, 1 \mathrm{H}, \mathrm{C}_{9}-\mathrm{H}\right) ; 2.48\left(\mathrm{~m}, 1 \mathrm{H}, \mathrm{C}_{16}-\mathrm{H}\right) ; 2.52(\mathrm{~m}, 1 \mathrm{H}$, $\left.\mathrm{C}_{12}-\mathrm{H}\right) ; 2.56\left(\mathrm{~m}, 1 \mathrm{H}, \mathrm{C}_{12}-\mathrm{H}\right) ; 2.70\left(\mathrm{~m}, 1 \mathrm{H}, \mathrm{C}_{12}-\mathrm{H}\right) ; 3.76$ (brs, $\left.1 \mathrm{H}, \mathrm{C}_{20}-\mathrm{H}\right)\left(4.61, \mathrm{~m}\right.$ in $\left.\mathrm{C}_{5} \mathrm{D}_{5} \mathrm{~N}\right) ; 3.76$ (brs, $\left.1 \mathrm{H}, \mathrm{C}_{21}-\mathrm{H}\right)\left(4.52, \mathrm{~m}\right.$ in $\left.\mathrm{C}_{5} \mathrm{D}_{5} \mathrm{~N}\right) ; 6.06\left(\mathrm{t}, 1 \mathrm{H}, J=1.26, \mathrm{C}_{4}-\mathrm{H}\right) ; 6.18\left(\mathrm{dd}, 1 \mathrm{H}, J=10.3,1.9, \mathrm{C}_{2}-\mathrm{H}\right) ; 7.67(\mathrm{~d}, 1 \mathrm{H}$, $\left.J=10.2, \mathrm{C}_{1}-\mathrm{H}\right) ;{ }^{13} \mathrm{C}-\mathrm{NMR}\left(\mathrm{CDCl}_{3}\right): \delta 15.9\left(\mathrm{C}_{18}\right) ; 19.3\left(\mathrm{C}_{19}\right) ; 24.5\left(\mathrm{C}_{15}\right) ; 34.8\left(\mathrm{C}_{7}\right) ; 35.0\left(\mathrm{C}_{6}\right) ; 33.4\left(\mathrm{C}_{16}\right)$; $37.7\left(\mathrm{C}_{8}\right) ; 44.1\left(\mathrm{C}_{10}\right) ; 49.5\left(\mathrm{C}_{14}\right) ; 52.7\left(\mathrm{C}_{12}\right) ; 52.8\left(\mathrm{C}_{13}\right) ; 61.3\left(\mathrm{C}_{9}\right) ; 65.0\left(\mathrm{C}_{21}\right) ; 72.5\left(\mathrm{C}_{20}\right) ; 85.0\left(\mathrm{C}_{17}\right) ; 124.6$ $\left(\mathrm{C}_{4}\right) ; 127.7\left(\mathrm{C}_{2}\right) ; 158.4\left(\mathrm{C}_{1}\right) ; 171.2\left(\mathrm{C}_{5}\right) ; 188.7\left(\mathrm{C}_{3}\right) ; 213.3\left(\mathrm{C}_{11}\right)$.

$11 \beta, 17 \alpha, 20 \beta, 21$-tetrahydroxy-1,4-pregnadiene-3-one (20ß-hydroxy-prednisolone): $\mathrm{mp} 185-187^{\circ} \mathrm{C}$; ${ }^{1} \mathrm{H}-\mathrm{NMR}\left(\mathrm{CDCl}_{3}\right): \delta 1.06\left(\mathrm{~s}, 3 \mathrm{H}, \mathrm{C}_{18}-\mathrm{CH}_{3}\right) ; 1.11\left(\mathrm{~m}, 1 \mathrm{H}, \mathrm{C}_{7}-\mathrm{H}\right) ; 1.12(\mathrm{~d}, J=10,1 \mathrm{H}, \mathrm{C}-\mathrm{H}) ; 1.44(\mathrm{~s}, 3 \mathrm{H}$, $\left.\mathrm{C}_{19}-\mathrm{CH}_{3}\right) ; 1.52\left(\mathrm{~m}, 1 \mathrm{H}, \mathrm{C}_{15}-\mathrm{H}\right) ; 1.54\left(\mathrm{~m}, 1 \mathrm{H}, \mathrm{C}_{16}-\mathrm{H}\right) ; 1.6\left(\mathrm{~m}, 1 \mathrm{H}, \mathrm{C}_{12}-\mathrm{H}\right) ; 1.77\left(\mathrm{~m}, 1 \mathrm{H}, \mathrm{C}_{14}-\mathrm{H}\right) ; 1.8(\mathrm{~m}, 1 \mathrm{H}$, $\left.\mathrm{C}_{15}-\mathrm{H}\right) ; 2.07\left(\mathrm{~m}, 1 \mathrm{H}, \mathrm{C}_{12}-\mathrm{H}\right) ; 2.12\left(\mathrm{~m}, 1 \mathrm{H}, \mathrm{C}_{7}-\mathrm{H}\right) ; 2.18\left(\mathrm{~m}, 1 \mathrm{H}, \mathrm{C}_{8}-\mathrm{H}\right) ; 2.23\left(\mathrm{~m}, 1 \mathrm{H}, \mathrm{C}_{6}-\mathrm{H}\right) ; 2.35\left(\mathrm{~m}, 1 \mathrm{H}, \mathrm{C}_{6}-\mathrm{H}\right) ;$ $2.45\left(\mathrm{~m}, 1 \mathrm{H}, \mathrm{C}_{16}-\mathrm{H}\right) ; 3.85\left(\mathrm{~m}, 1 \mathrm{H}, \mathrm{C}_{20}-\mathrm{H}\right) ; 3.91\left(\mathrm{~m}, 2 \mathrm{H}, \mathrm{C}_{21}-\mathrm{H}\right) ; 4.41\left(\mathrm{~s}, 1 \mathrm{H}, \mathrm{C}_{11}-\mathrm{H}\right) ; 6.02\left(\mathrm{~s}, 1 \mathrm{H}, \mathrm{C}_{4}-\mathrm{H}\right) ; 6.27$ $\left(\mathrm{dd}, J=10\right.$ and $\left.1.5,1 \mathrm{H}, \mathrm{C}_{2}-\mathrm{H}\right) ; 7.29\left(\mathrm{~d}, J=10,1 \mathrm{H}, \mathrm{C}_{1}-\mathrm{H}\right) ;{ }^{13} \mathrm{C}-\mathrm{NMR}\left(\mathrm{CDCl}_{3}\right): \delta 16.39\left(\mathrm{C}_{18}\right) ; 21.1\left(\mathrm{C}_{19}\right) ; 23.2$ $\left(\mathrm{C}_{15}\right) ; 33.5\left(\mathrm{C}_{7}\right) ; 31.9\left(\mathrm{C}_{6}\right) ; 35.3\left(\mathrm{C}_{16}\right) ; 33.2\left(\mathrm{C}_{8}\right) ; 42.2\left(\mathrm{C}_{10}\right) ; 55.1\left(\mathrm{C}_{14}\right) ; 47.4\left(\mathrm{C}_{12}\right) ; 46.9\left(\mathrm{C}_{13}\right) ; 55.5\left(\mathrm{C}_{9}\right) ; 65.3$ $\left(\mathrm{C}_{21}\right) ; 69.1\left(\mathrm{C}_{11}\right) ; 79.1\left(\mathrm{C}_{20}\right) ; 84.9\left(\mathrm{C}_{17}\right) ; 120.9\left(\mathrm{C}_{4}\right) ; 126.1\left(\mathrm{C}_{2}\right) ; 159.2\left(\mathrm{C}_{1}\right) ; 173.8\left(\mathrm{C}_{5}\right) ; 187.8\left(\mathrm{C}_{3}\right)$.

\section{Conclusions}

In this work the ability of some strains belonging to the Rhodococcus genus to biotransform cortisone and hydrocortisone was tested. The aim of this work was to find new active compounds and alternative methods to synthesize chemical products already known. To reach this goal, we performed a screening of several Rhodococcus strains as it has been shown in the literature that they have a high ability to biotransform many substances including steroids. Lab-scale experiments allowed us to identify the positive strains (strains with the capacity to transform the cortisone and/or hydrocortisone), and subsequently, the preparation on a semi-preparative scale of the same allowed for the characterization of the products obtained with the relative biotransformation yields. For both substrates used, $\Delta^{1}$-dehydrogenation products (e.g., prednisone and prednisolone) were obtained, in particular with $R$. coprophilus where the bioconversion yields were practically quantitative, making it a good candidate for the synthesis of prednisone and prednisolone using a method that follows the philosophy of green chemistry.

With regard to the reduction products at the level of the carbonyl group in $\mathrm{C}_{20}$, the stereochemistry of the hydroxyl group was carried out by comparing NMR spectra of known substances or commercial standards.

In these biotransformations, this type of product has been obtained with lower yields than those previously described. If of interest, it could be useful to study the reaction conditions in order to optimize the yield of generation of these compounds.

Author Contributions: Conceptualization and writing-review and editing S.C., investigation and analysis F.Z., B.S. and D.S., supervision and project administration G.F. All authors have read and agreed to the published version of the manuscript.

Funding: Ambrosialab: Ferrara, Italy (Grant 2019), Italian Ministry of Education University and Research (Grant MIUR-PRIN 2017E84AA4_002).

Acknowledgments: The authors would like to acknowledge Elisa Durini and Elisa Buzzi for technical assistance.

Conflicts of Interest: The authors declare no conflict of interest. 


\section{References}

1. Fernandes, P.; Cabral, J.M.S. Phytosterols: Applications and recovery methods. Bioresour. Technol. 2007, 98, 2335-2350. [CrossRef] [PubMed]

2. Hannich, J.T.; Umebayashi, K.; Riezman, H. Additional Perspectives on The Biology of Lipids. Cold Spring Harbour Perspect. Biol. 2011, 3, 4762-4763. [CrossRef] [PubMed]

3. Muthukrishnan, S.; Merzendorfer, H.; Arakane, Y.; Kramer, K.J. Chitin Metabolism in Insects. In Insect Molecular Biology and Biochemistry; Gilbert, L.I., Ed.; Elsevier: Amsterdam, The Netherlands, 2012; pp. 193-235.

4. Tong, W.Y.; Dong, X. Microbial Biotransformation: Recent Developments on Steroid Drugs. Recent Pat. Biotechnol. 2009, 3, 141-153. [CrossRef]

5. Fragkaki, A.G.; Angelis, Y.S.; Koupparis, M.; Tsantili-Kakoulidou, A.; Kokotos, G.; Georgakopoulos, C. Structural characteristics of anabolic androgenic steroids contributing to binding to the androgen receptor and to their anabolic and androgenic activities. Applied modifications in the steroidal structure. Steroids 2009, 74, 172-197. [CrossRef] [PubMed]

6. Agoston, E.S.; Hatcher, M.A.; Kensler, T.W.; Posner, G.H. Vitamin D Analogs as Anti-Carcinogenic Agents. Anti. Cancer Agents Med. Chem. 2006, 3, 53-71. [CrossRef]

7. Tuba, Z.; Bardin, C.W.; Dancsi, A.; Francsics-Czinege, E.; Molnár, C.; Csörgei, J.; Falkay, G.; Samuel, S. Synthesis and biological activity of a new progestogen, 16-methylene17 $\alpha$-hydroxy-18-methyl-19-norpregn-4-ene-3,20-dione acetate. Steroids 2000, 65, 266-274. [CrossRef]

8. Díaz-Chico, N.; Germán Rodríguez, F.; González, A.; Ramírez, R.; Bilbao, C.; Cabrera de León, A.; Aguirre Jaime, A.; Chirino, R.; Navarro, D.; Díaz-Chico, J.C. Androgens and androgen receptors in breast cancer. J.Steroid Biochem. 2007, 105, 1-15. [CrossRef]

9. Chrousos, G.P. Basic \& Clinical Pharmacology. In Adrenocorticosteroids \& Adrenocortical Antagonists, 13th ed.; McGraw-Hill Medical: New York, NY, USA, 2015.

10. Craigie, E.; Mullins, J.J.; Bailey, M.A. Glucocorticoids and mineralocorticoids. In Cardiovascular Hormone Systems: From Molecular Mechanisms to Novel Therapeutics; Bader, M., Ed.; Wiley-VCH Verlag GmbH \& Co: Weinheim, Germany, 2009; pp. 1-64.

11. Chung, S.K.; Ryooa, C.H.; Yang, H.W.; Shim, J.-Y.; Kang, M.G.; Lee, K.W.; Kang, H.I. Synthesis and bioactivities of steroid derivatives as antifungal agents. Tetrahedron 1998, 54, 1589-1591. [CrossRef]

12. Suzuki, K.; Nakata, T.; Shimizu, T. Anti-Obesity Agents Patent 5,846,962, 8 December 1998.

13. Dombrowski, A.W.; Hazuda, D.J.; Polishook, J.D.; Felock, P.J.; Singh, S.B.; Zink, D.L. HIV-Integrase-Inhibitors. World Patent 0036132, 22 June 2000.

14. Arthan, D.; Svasti, J.; Kittakoop, P.; Pittayakhachonwut, D.; Tanticharoen, M.; Thebtaranonth, Y. Antiviral isoflavonoid sulfate and steroidal glycosides from the fruits of Solanum torvum. Phytochemistry 2002, 59, 459-463. [CrossRef]

15. Funder, J.W. Minireview: Aldosterone and mineralocorticoid receptors: Past, present, and future. Endocrinology 2010, 151, 5098-5102. [CrossRef]

16. Zhang, H.; Tian, Y.; Wang, J.; Li, Y.; Wang, H.; Mao, S.; Liu, X.; Wang, C.; Bie, S.; Lu, F. Construction of engineered Arthrobacter simplex with improved performance for cortisone acetate biotransformation. Appl. Microbiol. Biotechnol. 2013, 97, 9503-9514. [CrossRef] [PubMed]

17. Samuel, S.; Nguyen, T.; Choi, H.A. Pharmacologic Characteristics of Corticosteroids. J. Neurocritical Care 2017, 10, 53-59. [CrossRef]

18. Olivetq, E.P.; Gould, D.H. US Patent 2.897.216, 28 July 1959.

19. Fernández-Cabezón, L.; Galán, B.; García, J. New Insights on Steroid Biotechnology. Front Microbiol. 2018, 15, 958-973. [CrossRef]

20. Mao, S.; Yu, L.; Ji, S.; Liu, X.; Lu, F. Evaluation of deep eutectic solvents as co-solvent for steroids 1-en-dehydrogenation biotransformation by Arthrobacter simplex. J. Chem. Technol. Biotechnol. 2016, 91, 1099-1104. [CrossRef]

21. Gao, Q.; Shen, Y.B.; Huang, W.; Wang, M. Effect of Natural Cyclodextrins on Cell Growth, Activity and Permeability of Arthrobacter simplex. Appl. Mech. Mater. 2015, 730, 249-253. [CrossRef] 
22. Luo, J.; Ning, J.; Wang, Y.; Cheng, Y.; Zheng, Y.; Shen, Y.; Wang, M. The effect of ethanol on cell properties and steroid 1-en-dehydrogenation biotransformation of Arthrobacter simplex. Biotechnol. Appl. Biochem. 2014, 61, 555-564. [CrossRef]

23. Spassov, G.; Krützfeldt, R.; Sheldrick, W.S.; Wania, W.; Vlahov, R.; Snatzke, G. Crystallographic monitoring of microbiological steroid transformations. Eur. J. Appl. Microbiol. Biotechnol. 1983, 17, 80-84. [CrossRef]

24. Vlahov, R.; Pramatarova, V.; Spassov, G.; Suchodolskaya, G.V.; Koshcheenko, K.A. Transformation of microcrystalline hydrocortisone by free and immobilized cells of Arthrobacter simplex. Appl. Microbiol. Biotechnol. 1990, 33, 172-175. [CrossRef]

25. Wang, X.; Feng, J.; Zhang, D.; Wu, Q.; Zhu, D.; Ma, Y. Characterization of new recombinant 3-ketosteroid- $\Delta 1$-dehydrogenases for the biotransformation of steroids. Appl. Microbiol. Biotechnol. 2017, 101, 6049-6060. [CrossRef]

26. Ghasemi, Y.; Rasoul-Amini, S.; Morowvat, M.H.; Raee, M.J.; Ghoshoon, M.B.; Nouri, F.; Negintaji, N.; Parvizi, R.; Mosavi-Azam, S.B. Characterization of Hydrocortisone Biometabolites and 18S rRNA Gene in Chlamydomonas reinhardtii Cultures. Molecules 2008, 13, 2416-2425. [CrossRef]

27. Bie, S.; Lu, F.; Liu, X.; Mao, S.; Li, J. Method for Manufacturing Prednisolone with Biotransformation. Patent CN 2012102505024 A 20120620, 20 June 2012.

28. Choudhary, M.I.; Siddiqui, Z.A.; Musharraf, S.G.; Nawaz, S.A. Microbial transformation of prednisone. Nat. Prod. Res. 2005, 19, 311-317. [CrossRef] [PubMed]

29. Zhang, W.; Cui, L.; Wu, M. Transformation of prednisolone to a $20 \beta$-hydroxy-prednisolone compound by Streptomyces roseochromogenes TS79. Appl. Microbiol. Biotechnol. 2011, 92, 727-735. [CrossRef] [PubMed]

30. Mohamed, S.S.; El-Hadi, A.A. Biotransformation of prednisolone to hydroxyl derivatives by Penicillium aurantium. Biocatal. Biotransformation 2017, 35, 215-222. [CrossRef]

31. Donova, M.V. Transformation of steroids by actinobacteria: A review. Appl. Biochem. Micro. 2007, 43, 1-14. [CrossRef]

32. Krivoruchko, A.; Kuyukina, M.; Ivshina, I. Advanced Rhodococcus Biocatalysts for Environmental Biotechnologies. Catalysts 2019, 9, 236-255. [CrossRef]

33. Lichtinger, T.; Reiss, G.; Benz, R. Biochemical identification and biophysical characterization of a channel-forming protein from Rhodococcus erythropolis. J. Bacteriol. 2000, 182, 764-770. [CrossRef]

34. Patrauchan, M.A.; Florizone, C.; Dosanjh, M.; Mohn, W.W.; Davies, J.; Eltis, L.D. Catabolism of benzoate and phthalate in Rhodococcus sp. strain RHA1: Redundancies and convergence. J. Bacteriol. 2005, 187, 4050-4063. [CrossRef]

35. Costa, S.; Giovannini, P.P.; Fantin, G.; Medici, A.; Pedrini, P. New 9,10-secosteroids from biotransformations of bile acids with Rhodococcus ruber. Helv. Chim. Acta 2013, 96, 2124-2133. [CrossRef]

36. Costa, S.; Giovannini, P.P.; Fantin, G.; Medici, A.; Pedrini, P. New 9,10-secosteroids from biotransformations of hyodeoxycholic acid with Rhodococcus spp. Helv. Chim. Acta 2013, 96, 1062-1071. [CrossRef]

37. Horinouchi, M.; Hayashi, T.; Kudo, T. Steroid degradation in Comamonas testosteroni. J. Steroid Biochem. Mol. Biol. 2012, 129, 4-14. [CrossRef]

38. Hu, Y.; Van Der Geize, R.; Besra, G.S.; Gurcha, S.S.; Liu, A.; Rohde, M.; Singh, M.; Coates, A. 3-Ketosteroid $9 \alpha$-hydroxylase is an essential factor in the pathogenesis of Mycobacterium tuberculosis. Mol. Microbiol. 2010, 75, 107-121. [CrossRef] [PubMed]

39. Capyk, J.K.; D'Angelo, I.; Strynadka, N.C.; Eltis, L.D. Characterization of 3-ketosteroid $9 \alpha$-hydroxylase, a Rieske oxygenase in the cholesterol degradation pathway of Mycobacterium tuberculosis. J. Biol. Chem. 2009, 284, 9937-9946. [CrossRef] [PubMed]

40. Petrusma, M.; Dijkhuizen, L.; Van Der Geize, R. Rhodococcus rhodochrous DSM 43269 3-ketosteroid $9 \alpha$-hydroxylase, a two-component iron-sulfur-containing monooxygenase with subtle steroid substrate specificity. Appl. Environ. Microbiol. 2009, 75, 5300-5307. [CrossRef] [PubMed]

41. Park, R.J. Phenolic 9,10-secosteroids as products of the catabolism of bile acids by a Pseudomonas sp. Steroids 1984, 44, 175-193. [CrossRef]

(C) 2020 by the authors. Licensee MDPI, Basel, Switzerland. This article is an open access article distributed under the terms and conditions of the Creative Commons Attribution (CC BY) license (http://creativecommons.org/licenses/by/4.0/). 